\title{
TINGKAT PENGETAHUAN CIVITAS AKADEMIKA KESEHATAN DIBANDINGKAN NON KESEHATAN TENTANG KANKER SERVIKS DAN VAKSINASI HPV DI SLEMAN
}

\section{KNOWLEDGE ON CERVICAL CANCER AND HUMAN PAPILLOMA VIRUS VACCINATION BETWEEN HEALTH AND NON HEALTH STUDENT OF UNIVERSITY IN SLEMAN YOGYAKARTA}

\author{
Ndaru Setyaningrum ${ }^{1 *}$, Uzlah Fawati Zuar ${ }^{1}$, Ninisita Sri Hadi ${ }^{2}$ \\ ${ }^{1}$ Universitas Islam Indonesia, \\ Jl. Kaliurang .Km. 14, No. 4, Lodadi, Umbulmartani, Ngemplak, Sleman \\ ${ }^{2}$ Praktisi Promosi Kesehatan Masyarakat \\ *Penulis korepondensi, e-mail : $126150101 @$ uii.ac.id
}

\begin{abstract}
ABSTRAK
Kanker serviks merupakan jenis kanker yang menimbulkan kematian tertinggi pada wanita. Tingkat pengetahuan mahasiswa mengenai kanker serviks dan vaksinasi HPV masih tergolong rendah. Penelitian ini bertujuan untuk mengetahui tingkat pengetahuan civitas akademika kesehatan dibandingkan non kesehatan tentang kanker serviks dan vaksinasi HPV di Sleman Yogyakarta. Penelitian ini merupakan jenis penelitian deskriptif dengan pendekatan cross sectional. Pemilihan sampel menggunakan teknik cluster random sampling untuk menentukan jurusan dan perguruan tinggi di Kabupaten Sleman. Pengambilan data dilakukan menggunakan kuesioner pada bulan Agustus - September 2016. Subjek penelitian terdiri dari civitas akedemika kesehatan 120 responden dan non kesehatan 80 responden. Analisis data dilakukan secara univariat dan bivariat. Tingkat pengetahuan diolah secara deskriptif sedangkan perbedaan tingkat pengetahuan antara civitas akademika kesehatan dan non kesehatan dilakukan uji Mann Whitney. Sejumlah $8(6,67 \%)$ responden kesehatan sudah melakukan vaksinasi HPV. Rata rata tingkat pengetahuan civitas akademika bidang kesehatan lebih baik dibandingkan non kesehatan. Tingkat pengetahuan kategori baik terkait kanker serviks dan vaksinasi HPV untuk responden kesehatan berturut - turut 90(74,69\%) dan $87(72,22 \%)$ sedangkan non kesehatan berturut - turut $53(66,41 \%)$ dan $52(64,79 \%)$. Sebagian besar responden kesehatan $(90,28 \%)$ dan non kesehatan $(88,75 \%)$ memiliki persepsi positif terhadap vaksinasi HPV. Tingkat pengetahuan responden kesehatan mengenai kanker serviks dan vaksinasi HPV lebih baik dibandingkan responden non kesehatan, namun tidak berbeda signifikan secara statistik $(\mathrm{p}>0,05)$.
\end{abstract}

Kata kunci : Pengetahuan, kanker serviks, vaksinasi HPV, kesehatan, non kesehatan

\begin{abstract}
Cervical cancer is a type of cancer that causes the highest death in women. The level of knowledge of adolescents about cervical cancer and HPV vaccination is still relatively low. This study aims to determine the level of knowledge of the health academics compared to non-health
\end{abstract}


about cervical cancer and HPV vaccination in Sleman Yogyakarta. This research is a type of descriptive research with cross sectional approach. The sample selection uses a cluster random sampling technique to determine majors and universities in Sleman Regency. Data collection was carried out using a questionnaire in August - September 2016. The research subjects consisted of 120 academic respondents and 80 respondents were non-healthcare. Data analysis was performed univariate and bivariate. The level of knowledge is processed descriptively while the difference in the level of knowledge between the health and non-health academic community is carried out by the Mann Whitney test. A total of $8(6.67 \%)$ health respondents had already had HPV vaccinations. The average level of knowledge of the academic community is better than not the health community. The level of knowledge both categories related to cervical cancer and HPV vaccination for health respondents respectively 90 (74.69\%) and 87 (72.22\%) while non-health respectively $53(66.41 \%)$ and 52 (64.79) \%). Most of the health respondents (90.28\%) and non-health (88.75\%) had positive perceptions of HPV vaccination. The level of knowledge of health respondents about cervical cancer and HPV vaccination was better than non-health respondents, although it was not statistically significant difference ( $p>0.05$ ).

Keywords: Knowledge, cervical cancer, HPV vaccination, health, non health

\section{PENDAHULUAN}

Menurut data Centers for Disease Control and Prevention (CDC) prevalensi kanker serviks pada wanita sekitar 11.955 orang dan lebih dari sepertiga meninggal akibat kanker serviks (CDC, 2016). Kematian akibat kanker serviks akan terus meningkat 25\% dalam 10 tahun mendatang (Zimet et al., 2010). Indonesia diperkirakan terjadi kasus 180.000 kanker baru tiap tahun dengan kanker serviks menempati urutan pertama kanker pada wanita. Prevalensi kanker serviks di Daerah Istimewa Yogyakarta tahun 2013 sebesar 2.703 kasus sehingga menempati urutan ketujuh dari 34 provinsi di Indonesia (Kemenkes, 2015).

Studi di Indonesia menunjukkan bahwa Human papillomavirus (HPV) ditemukan pada 96\% pasien kanker serviks dan 83\% diantaranya adalah HPV 18 dan HPV 16 (Kemenkes, 2015). Vaksinasi HPV terbukti dapat mencegah kejadian kanker serviks hingga 70\% (Zimet, et al., 2010). Vaksinasi HPV mampu mengurangi infeksi HPV lebih dari 90\%. Efektivitas vaksinasi HPV paling baik dilakukan pada usia 18-19 tahun. Efektivitas vaksin HPV akan berkurang pada wanita yang melakukan vaksinasi di usia yang lebih dewasa (WHO, 2007). Sejumlah besar negara Eropa, Amerika, Australia, dan Selandia Baru telah merekomendasikan vaksinasi HPV masuk dalam program vaksinasi sekolah untuk remaja perempuan (Arbyn and Oyen, 2000). 
Berdasarkan hasil penelitian Sulistiowati (2014) bahwa tingkat pengetahuan responden mengenai faktor risiko, perilaku dan deteksi dini kanker serviks masih tergolong rendah. Tingkat pengetahuan siswi SMA di Kabupaten Badung tentang kanker serviks masih rendah. Hal tersebut disebabkan informasi kesehatan terkait kanker serviks masih terbatas (Dethan and Suariyani, 2017). Responden dengan latar belakang pendidikan bidang kesehatan dan memiliki akses informasi kesehatan memiliki tingkat pengetahuan baik tentang kanker serviks (Rachmani et al., 2012). Lebih dari 60\% mahasiswa kebidanan Universitas Islam Negeri Alauddin Makassar memiliki tingkat pengetahuan baik mengenai tujuan vaksinasi HPV (Safitry, 2016).

Mahasiswa bidang kesehatan berperan sebagai calon tenaga kesehatan dituntut mampu memberikan edukasi kesehatan salah satunya terkait kanker serviks dan vaksinasi HPV. Meskipun demikian, penelitian yang membandingkan tingkat pengetahuan antara mahasiswa kesehatan dengan non kesehatan tentang kanker serviks dan vaksinasi HPV belum banyak dilakukan. Penelitian ini dilakukan untuk mengetahui tingkat pengetahuan dan persepsi tentang kanker serviks dan vaksinasi HPV pada civitas akademika kesehatan dan non kesehatan.

\section{METODE PENELITIAN}

Penelitian ini merupakan jenis penelitian deskriptif observasional dengan pendekatan cross sectional. Pemilihan sampel menggunakan teknik cluster random sampling untuk menentukan jurusan dan perguruan tinggi di Kabupaten Sleman. Mahasiswa non kesehatan yang menjadi responden adalah mahasiswa jurusan ekonomi UPN dan Sastra Inggris UTY, sedangkan mahasiswa kesehatan dilakukan sampling dari jurusan farmasi UII, kedokteran hewan UGM dan kebidanan Unisia. Mahasiswa kedokteran hewan dilibatkan dalam penelitian ini disebabkan studi pada hewan dapat diekstrapolasikan secara linier terhadap manusia. Efektivitas vaksin pada hewan juga menunjukkan keberhasilan pada manusia, meskipun jenis paparan virus bersifat spesifik, HPV tidak menginfeksi hewan dan papillomavirus hewan tidak bisa menginfeksi manusia (Houtman, 2008).

Perhitungan besar sampel dengan tingkat kemaknaan 10\% dari populasi sejumlah 
250.000 diperoleh total 100 responden dengan menyesuaikan proporsi jumlah mahasiswa tiap perguruan tinggi. Perhitungan besar sampel minimal untuk penelitian ini menggunakan persamaan 1 .

$\mathrm{n}=\frac{Z^{2} 1-\frac{\dot{\alpha}}{2} P(1-P)}{d^{2}}$

$\mathrm{n}=\underline{1,96^{2}(0,5)(0,5)}$

$(0,1)^{2}$

$\mathrm{n}=96,04$

Pengambilan data dilakukan pada bulan Agustus - September 2016. Alat penelitian berupa kuesioner untuk mengetahui tingkat pengetahuan dan persepsi mahasiswa mengenai kanker serviks dan vaksinasi HPV. Kuesioner ini dibuat sendiri oleh peneliti dengan modifikasi dari beberapa hasil publikasi jurnal meliputi : Knowloedge of Human Papilloma Virus And Acceptability to Vaccinate in Adolescents and Young Adults of the Moroccan Population (Zouheir et al., 2016). Knowledge and perception on human papilloma virus infection and vaccination among medical students of a university in Malaysia (Shafei, 2014); Pengetahuan dan sikap tentang perilaku vaksinasi HPV pada siswi SMA swasta (Dethan and Suariyani, 2017).

Kuesioner disusun terdiri dari 3 bagian. Bagian pertama dan kedua untuk menggali tingkat pengetahuan mengenai kanker serviks dan vaksinasi HPV masing masing terdiri dari 8 dan 6 butir pertanyaan. Pengetahuan kanker serviks yang ingin dilihat adalah penyebabnya, faktor risiko dan cara pencegahannya. Pengetahuan vaksinasi HPV ingin dilihat bagaimana pengenalan responden terhadap vaksinasi HPV, efek dan waktu pemberiannya. Bagian ketiga terdiri dari 6 pertanyaan untuk mengukur persepsi responden tentang vaksinasi HPV. Persepsi yang dimaksud adalah terkait efektivitas vaksinasi, persetujuan program vaksinasi dan biaya vaksinasi.

Peneliti melakukan uji validitas dan reliabilitas menggunakan 30 responden. Hasil pengujian diperoleh nilai rerata korelasi dan cronbach alpha masing - masing lebih dari 0,361 dan 0,785. Berdasarkan hasil tersebut peneliti melanjutkan penelitian menggunakan kuesioner yang telah disusun.

Hasil pengisian kuesioner diolah dan disajikan secara deskriptif. Kategori 
tingkat pengetahuan baik jika responden menjawab benar $>80 \%$, sedang $60-80 \%$ dan rendah $<60 \%$. Persepsi dikategorikan sebagai persepsi positif jika jawaban positif $>70 \%$ dan persepsi negatif jika nilai responden $<70 \%$.

\section{HASIL DAN PEMBAHASAN}

Karakteristik subjek penelitian seperti terlihat pada Tabel I. sebagian besar merupakan mahasiswa berusia 18 - 25 tahun dengan pendidikan kesehatan sejumlah $105(87,5 \%)$ dan non kesehatan $70(87,5 \%)$. Jumlah responden staf kependidikan/dosen untuk program studi kesehatan dan non kesehatan masing - masing sebanyak 15 $(12,5 \%)$ dan 10 (12,5\%). Responden dengan status menikah sejumlah 12 (10\%) untuk program kesehatan dan $12(15 \%)$ untuk program non kesehatan. Berdasarkan data diketahui ada 2 responden mahasiswa telah menikah. Vaksinasi HPV sudah dilakukan oleh $8(6,67 \%)$ responden kesehatan, sedangkan responden non kesehatan belum ada yang melakukan vaksinasi HPV.

Tabel I. Karakteristik demografi responden

\begin{tabular}{|c|c|c|c|}
\hline No. & Karakteristik & $\begin{array}{c}\text { Kesehatan } \\
\mathrm{N}(\%)\end{array}$ & $\begin{array}{c}\text { Non Kesehatan } \\
\mathbf{N}(\%)\end{array}$ \\
\hline \multirow{3}{*}{1.} & Usia & & \\
\hline & 18-25 tahun & $105(87,5)$ & $70(87,5)$ \\
\hline & $>25-49$ tahun & $15(12,5)$ & $10(12,5)$ \\
\hline \multirow{4}{*}{2.} & Tingkat Pendidikan & & \\
\hline & Mahasiswi & $105(87,5)$ & $70(87,5)$ \\
\hline & S1 & $5(4,17)$ & $5(6,25)$ \\
\hline & S2 & $10(8,33)$ & $5(6,25)$ \\
\hline \multirow{3}{*}{3.} & Pekerjaan & & \\
\hline & Mahasiswi & $105(87,5)$ & $70(87,5)$ \\
\hline & Staf kependidikan/dosen & $15(12,5)$ & $10(12,5)$ \\
\hline \multirow{3}{*}{4.} & Status pernikahan & & \\
\hline & Menikah & $12(10)$ & $12(15)$ \\
\hline & Belum menikah & 108(90) & $68(85)$ \\
\hline \multirow{3}{*}{5.} & Vaksinasi HPV & & \\
\hline & Melakukan & $8(6,67)$ & $0(0)$ \\
\hline & Tidak melakukan & $112(93,3)$ & $80(100)$ \\
\hline & Total N(\%) & 120(100) & $80(100)$ \\
\hline
\end{tabular}

(Sumber : Data Primer, 2016) 
Rata - rata tingkat pengetahuan civitas akademika bidang kesehatan lebih baik dibandingkan non kesehatan. Tingkat pengetahuan terkait kanker serviks Tabel II maupun vaksinasi HPV Tabel III responden kesehatan lebih baik dibanding non kesehatan. Hampir semua pertanyaan terkait kanker serviks dan vaksinasi HPV dijawab secara benar oleh lebih dari $85 \%$ responden kesehatan. Beberapa aspek yang masih perlu edukasi adalah faktor risiko merokok, penggunaan alat kontrasepsi dan gejala perdarahan di luar siklus menstruasi sebagai kewaspadaan gejala kanker serviks. Pengetahuan tentang vaksinasi HPV yang masih memerlukan edukasi adalah bagaimana efek vaksinasi HPV terhadap pencegahan infeksi menular seksual, usia dan frekuensi paling efektif dilakukan vaksinasi HPV.

Jumlah responden non kesehatan yang menjawab benar pengetahuan tentang kanker serviks dan vaksinasi HPV sejumlah $80 \%$, tidak mencapai $85 \%$. Pengetahuan terkait kanker serviks yang mampu dijawab benar $80 \%$ responden adalah HPV sebagai penyebab kanker serviks dan seks bebas sebagai faktor risiko penularan kanker serviks. Pengetahuan responden terkait vaksinasi HPV yang dijawab dengan benar $80 \%$ responden adalah terkait pengenalan dan efektivitas vaksinasi HPV sebagai pencegahan kanker serviks.

Sebagian besar responden kesehatan $(90,28 \%)$ dan non kesehatan $(88,75 \%)$ memiliki persepsi positif terhadap vaksinasi HPV. Responden kesehatan $(91,67 \%)$ dan non kesehatan $(93,75 \%)$ mengakui efektivitas vaksinasi HPV dalam mencegah kanker serviks. Hampir seluruh responden kesehatan $(95,83 \%)$ dan non kesehatan $(93,75 \%)$ merasa vaksinasi HPV wajib dilakukan setiap perempuan. Responden kesehatan $(92,5 \%)$ dan non kesehatan $(88,75 \%)$ setuju untuk melakukan vaksinasi HPV. Responden kesehatan $(85,83 \%)$ dan non kesehatan $(81,25 \%)$ setuju bahwa vaksinasi HPV penting mencegah kanker serviks. Sebagian besar responden kesehatan $(79,17 \%)$ dan non kesehatan $(82,5 \%)$ terkendala dengan biaya untuk melakukan vaksinasi. Sebagian besar responden kesehatan $(96,67 \%)$ dan non kesehatan $(92,5 \%)$ setuju jika pemerintah memberikan subsidi bagi perempuan untuk melakukan vaksinasi HPV (Tabel IV). 
Tabel II. Tingkat pengetahuan responden tentang kanker serviks

\begin{tabular}{|c|c|c|c|c|}
\hline \multirow[t]{2}{*}{ Pernyataan } & \multicolumn{2}{|c|}{ Kesehatan } & \multicolumn{2}{|c|}{ Non Kesehatan } \\
\hline & $\begin{array}{l}\text { Benar } \\
\mathrm{N}(\%)\end{array}$ & $\begin{array}{l}\text { Salah } \\
\text { N(\%) }\end{array}$ & $\begin{array}{l}\text { Benar } \\
\mathrm{N}(\%)\end{array}$ & $\begin{array}{l}\text { Salah } \\
\text { N(\%) }\end{array}$ \\
\hline HPV sebagai penyebab kanker serviks & $117(97,5)$ & $3(2,5)$ & $66(82,5)$ & $14(17,5)$ \\
\hline $\begin{array}{l}\text { Usia terdiagnosa kanker serviks rentang } 30-50 \\
\text { tahun }\end{array}$ & 102(85) & $18(15)$ & $59(73,75)$ & $21(26,25)$ \\
\hline $\begin{array}{l}\text { Hubungan seks bebas merupakan faktor risiko } \\
\text { kanker serviks }\end{array}$ & $105(87,5)$ & $15(12,5)$ & $64(80)$ & $16(20)$ \\
\hline $\begin{array}{l}\text { Merokok merupakan faktor risiko kanker } \\
\text { serviks }\end{array}$ & $43(35,83)$ & $77(64,17)$ & $38(47,5)$ & $42(52,5)$ \\
\hline $\begin{array}{l}\text { Penggunaan alat kontrasepsi merupakan faktor } \\
\text { risiko kanker serviks }\end{array}$ & $59(49,17)$ & $61(50,83)$ & $28(35)$ & $52(65)$ \\
\hline $\begin{array}{l}\text { Vaksinasi HPV merupakan cara pencegahan } \\
\text { kanker serviks }\end{array}$ & $97(80,83)$ & $23(19,17)$ & $56(70)$ & $24(30)$ \\
\hline $\begin{array}{l}\text { Pap Smear merupakan cara pencegahan kanker } \\
\text { serviks }\end{array}$ & $105(87,5)$ & $15(12,5)$ & $61(76,25)$ & $19(23,75)$ \\
\hline $\begin{array}{l}\text { Pendarahan di luar siklus menstruasi perlu } \\
\text { diwaspadai sebagai gejala kanker serviks }\end{array}$ & $89(74,17)$ & $31(25,83)$ & $53(66,25)$ & $27(33,75)$ \\
\hline Total N(\%) & 120 & 100) & 80( & 100) \\
\hline
\end{tabular}

(Sumber : Data Primer, 2016)

Tabel III. Tingkat pengetahuan responden tentang vaksinasi HPV

\begin{tabular}{lcccc}
\hline \multicolumn{1}{c}{ Pernyataan } & \multicolumn{2}{c}{ Kesehatan } & \multicolumn{2}{c}{ Non Kesehatan } \\
& Benar & Salah & Benar & Salah \\
& N(\%) & N(\%) & N(\%) & N(\%) \\
\hline $\begin{array}{l}\text { Pengenalan terhadap vaksinasi HPV } \\
\text { Vaksinasi HPV dapat menyembuhkan infeksi }\end{array}$ & $114(95)$ & $6(5)$ & $66(82,5)$ & $14(17,5)$ \\
HPV & $102(85)$ & $18(15)$ & $59(73,75)$ & $21(26,25)$ \\
Vaksinasi HPV 100\% mencegah kanker serviks & $105(87,5)$ & $15(12,5)$ & $64(80)$ & $16(20)$ \\
$\begin{array}{l}\text { Vaksinasi HPV mencegah infeksi menular } \\
\text { seksual }\end{array}$ & $43(35,83)$ & $77(64,17)$ & $38(47,5)$ & $42(52,5)$ \\
$\begin{array}{l}\text { Vaksinasi HPV efektif dilakukan usia 8-19 } \\
\text { tahun }\end{array}$ & $59(49,17)$ & $61(50,83)$ & $28(35)$ & $52(65)$ \\
$\begin{array}{l}\text { Vaksinasi HPV efektif dilakukan 1x seumur } \\
\text { hidup }\end{array}$ & $97(80,83)$ & $23(19,17)$ & $56(70)$ & $24(30)$ \\
Total N(\%) & \multicolumn{2}{c}{$120(100)$} & & $80(100)$ \\
\hline
\end{tabular}

(Sumber : Data Primer, 2016) 
Tabel IV. Persepsi responden tentang vaksinasi HPV sebagai pencegahan kanker serviks

\begin{tabular}{|c|c|c|c|c|c|c|c|c|}
\hline \multirow[t]{3}{*}{ Pernyataan } & \multicolumn{4}{|c|}{ Kesehatan } & \multicolumn{4}{|c|}{ Non Kesehatan } \\
\hline & \multicolumn{2}{|c|}{ Positif N(\%) } & \multicolumn{2}{|c|}{ Negatif $\mathbf{N}(\%)$} & \multicolumn{2}{|c|}{ Positif N(\%) } & \multicolumn{2}{|c|}{ Negatif $N(\%)$} \\
\hline & SS & $\mathbf{S}$ & TS & STS & SS & $\mathbf{S}$ & TS & STS \\
\hline $\begin{array}{l}\text { Vaksinasi } \\
\text { HPV efektif } \\
\text { mencegah } \\
\text { kanker } \\
\text { serviks }\end{array}$ & $14(11,67)$ & $96(80)$ & $9(7,5)$ & $1(0,83)$ & $24(30)$ & $51(63,75)$ & $5(6,25)$ & $0(0)$ \\
\hline $\begin{array}{l}\text { Vaksinasi } \\
\text { HPV wajib } \\
\text { dilakukan } \\
\text { setiap } \\
\text { perempuan }\end{array}$ & $55(45,83)$ & $60(50)$ & $5(4,16)$ & $0(0)$ & $39(48,75)$ & $36(45)$ & $5(6,25)$ & $0(0)$ \\
\hline $\begin{array}{l}\text { Persetujuan } \\
\text { melakukan } \\
\text { vaksinasi } \\
\text { HPV }\end{array}$ & $38(31,67)$ & $73(60,83)$ & $7(5,83)$ & $2(1,67)$ & $31(38,75)$ & $40(50)$ & $9(11,25)$ & $0(0)$ \\
\hline $\begin{array}{l}\text { Vaksinasi } \\
\text { HPV } \\
\text { penting } \\
\text { untuk } \\
\text { mencegah } \\
\text { kanker } \\
\text { serviks }\end{array}$ & $25(20,83)$ & $78(65)$ & $17(14,16)$ & $0(0)$ & $30(37,5)$ & $35(43,75)$ & $14(17,5)$ & $1(1,25)$ \\
\hline $\begin{array}{l}\text { Biaya } \\
\text { merupakan } \\
\text { faktor } \\
\text { penghambat } \\
\text { perempuan } \\
\text { melakukan } \\
\text { vaksinasi } \\
\text { HPV }\end{array}$ & $34(28,33)$ & $61(50,83)$ & $24(20)$ & $1(0,83)$ & $35(43,75)$ & $31(38,75)$ & $14(17,5)$ & $0(0)$ \\
\hline $\begin{array}{l}\text { Pemerintah } \\
\text { perlu } \\
\text { memberikan } \\
\text { subsidi } \\
\text { vaksinasi } \\
\text { HPV }\end{array}$ & $63(52,5)$ & $53(44,16)$ & $4(3,33)$ & $0(0)$ & $49(61,25)$ & $25(31,25)$ & $6(7,5)$ & $0(0)$ \\
\hline
\end{tabular}

(Sumber : Data Primer, 2016)

Keterangan : SS (sangat setuju), S (setuju), TS (tidak setuju), STS (sangat tidak setuju) 
Meskipun secara deskriptif menunjukkan bahwa responden kesehatan berpengetahuan lebih baik dibandingkan non kesehatan, akan tetapi berdasarkan analisis statistik perbedaan tersebut tidak bermakna signifikan. Latar belakang pendidikan kesehatan dan non kesehatan dalam penelitian ini tidak berpengaruh signifikan terhadap tingkat pengetahuan mengenai kanker serviks dan vaksinasi HPV $(p=0,066)$. Jenis variabel demografi yang berhubungan signifikan dengan tingkat pengetahuan responden adalah usia $(\mathrm{p}=0,013)$ dan status pernikahan $(\mathrm{p}=0,016)$.

Berdasarkan data karakteristik subjek penelitian bahwa responden kesehatan lebih waspada dalam upaya pencegahan kanker serviks. Hal ini ditandai dengan data bahwa sejumlah $8(6,67 \%)$ responden kesehatan telah melakukan vaksinasi sementara responden non kesehatan belum ada yang melakukan vaksinasi. Hal ini sejalan dengan hasil penelitian Dethan (2017) bahwa pendidikan bidang kesehatan berpengaruh terhadap tingkat pengetahuan yang selanjutnya menentukan sikap seseorang (Dethan and Suariyani, 2017; Rachmani et al., 2012).

Responden mahasiswa non kesehatan diketahui 2 (2,5\%) telah menikah meskipun tidak diketahui pada usia berapa tahun responden menikah. Usia pernikahan berpengaruh terhadap kejadian kanker serviks. Pernikahan dini menimbulkan frekuensi aktivitas seksual lebih tinggi. Semakin tinggi aktivitas seksual meningkatkan risiko perubahan konsistensi servik yang memicu terjadinya pertumbuhan sel yang abnormal berupa kanker (Joeharno, 2011). Perempuan yang melakukan aktivitas seksual sebelum usia 18 tahun berisiko terjadi kanker serviks lima kali lipat (Rasjidi, 2009).

Berdasarkan hasil penelitian secara deskritif bahwa rata - rata tingkat pengetahuan responden kesehatan lebih baik dibandingkan non kesehatan. Hasil penelitian ini sejalan dengan studi Handayani dkk (2013) bahwa mahasiswa kesehatan memiliki pengetahuan signifikan lebih baik dibanding non kesehatan dalam swamedikasi (Handayani, 2013). Mahasiswa kesehatan memiliki kesempatan lebih baik untuk mengetahui informasi tentang kesehatan dari dosen, seminar maupun sumber informasi dari media cetak dan elektronik. Meskipun demikian responden kesehatan masih perlu edukasi terkait faktor risiko non seksual seperi merokok dan penggunaan kontrasepsi. 
Merokok termasuk faktor risiko kanker serviks yang telah dibuktikan. Merokok berhubungan dengan kanker sel skuamosa pada serviks. Pada lendir mulut rahim wanita perokok ditemukan zat karsinogenik spesifik dari tembakau. Zat karsinogenik tersebut dapat merusak DNA sel epitel skuamosa dan bersama infeksi HPV dapat bertransformasi menjadi keganasan. Penggunaan kontrasepsi oral merupakan faktor risiko yang diperkirakan. Risiko noninvasif dan invasif kanker serviks telah menunjukkan hubungan dengan kontrasepsi oral. Meskipun demikian beberapa studi belum konsisten menunjukkan hubungan penggunaan kontrasepsi dengan kejadian kanker serviks (Rasjidi, 2009).

Sebagian besar responden non kesehatan telah mengenal dan pernah tahu tentang vaksinasi HPV (82,5\%). Kemudahan mengakses informasi dari berbagai sumber memungkinkan seseorang dengan pendidikan non kesehatan mengetahui informasi kesehatan. Faktor tersebut sejalan dengan studi Rachmani (2012) bahwa informasi dari media cetak dan elektronik mempengaruhi tingkat pengetahuan responden. Untuk topik kesehatan umum faktor latar belakang pendidikan tidak selalu berkorelasi dengan tingkat pengetahuan. Studi Rohmawati (2016) menunjukkan pola swamedikasi antara mahasiswa kesehatan dan non kesehatan tidak berbeda signifikan. Hal ini kemungkinan karena responden dapat membaca sebagian informasi obat dari label produk obat.

Responden kesehatan maupun non kesehatan masih berpengetahuan kurang mengenai manfaat vaksinasi dihubungkan dengan infeksi menular seksual dan usia ideal dilakukan vaksinasi HPV. Human papilloma virus dapat menimbulkan infeksi kelamin berupa penyakit kutil kelamin dan kanker serviks. Vaksinasi HPV dapat mencegah infeksi kelamin akibat infeksi human papilloma virus saja, tidak dapat mencegah semua jenis infeksi menular seksual (CDC, 2017). Sebagian besar responden kesehatan dan non kesehatan juga belum mengetahui rentang usia efektif dilakukan vaksinasi HPV. Vaksinasi HPV paling efektif untuk perempuan usia 12-16 tahun. Meskipun demikian efektivitas vaksinasi menurun seiring dengan meningkatnya usia vaksinasi hingga 25 tahun (Westra et al., 2011).

Sebagian besar responden kesehatan $(90,28 \%)$ dan non kesehatan $(88,75 \%)$ memiliki persepsi positif terhadap vaksinasi HPV. Hasil ini sejalan dengan penelitian 
Rachmani (2012) bahwa sebagian besar remaja (92,9\%) mendukung vaksinasi HPV untuk mencegah kanker serviks. Faktor yang mempengaruhi sikap remaja perempuan terhadap vaksinasi HPV antara lain keyakinan terhadap manfaat vaksinasi HPV, pengetahuan tentang kanker serviks dan vaksin HPV serta sikap keluarga terhadap vaksinasi HPV. Responden yang tidak melakukan vaksinasi HPV dikarenakan belum pernah mendapatkan informasi tentang vaksinasi HPV (Sari and Syahrul, 2014). Pengetahuan responden merupakan faktor yang menentukan persepsi dan selanjutnya sikap responden.

Faktor usia dan status pernikahan merupakan karakteristik demografi yang berhubungan signifikan dengan tingkat pengetahuan responden mengenai kanker serviks dan vaksinasi HPV. Sebelum pernikahan seseorang cenderung mempersiapkan fisik, mental dan pengetahuan tentang kesehatan reproduksi. Hal ini didorong oleh kesadaran dan kewaspadaan terhadap gangguan reproduksi paska hubungan seksual. Vaksinasi HPV sebagian besar dilakukan oleh wanita yang sudah menikah. Faktor usia menentukan kematangan berpikir dan keluasan wawasan seseorang. Tindakan vaksinasi HPV sebagian besar dilakukan oleh responden dengan usia > 25 tahun (Sari and Syahrul, 2014).

\section{KESIMPULAN}

Tingkat pengetahuan responden kesehatan lebih baik dibandingkan responden non kesehatan tidak berbeda signifikan secara statistik $(\mathrm{p}>0,05)$.

\section{DAFTAR PUSTAKA}

CDC. 2016. United States Cancer Statistics: 1999-2013 Incidence and Mortality Webbased Report. U.S. Cancer Statistics Working Group. Atlanta (GA): Department of Health and Human Services, Centers for Disease Control and Prevention, and National Cancer Institute; Available at: http://www.cdc.gov/uscs.

Zimet, Gregory D. Weiss, Thomas W. Rosenthal, Susan L. Good, Margaret B. Vichnin, Michelle D. 2010. Reason for non-Vaccinating Against HPV and Future Vaccination Intention Among 19-26 Year Old Women.BioMed Central Women's Health:10(27). 
Kementerian Kesehatan Republik Indonesia. 2015. Pusat data dan informasi, Bulletin Jendela Data dan Informasi Kesehatan: Situasi Penyakit Kanker;.pp.4.

Rasjidi. 2009. Epidemilogi kanker serviks. Indonesian Journal of Cancer:III(3).

World Health Organization. 2007. Human Papilloma Virus and HPV Vaccine.. Diakses melalui: http://whqlibdoc.who.int/hq/2007/WHO_IVB_07.05_eng.pdf.

Arbyn M. \& Oyen H.V. 2000. Cervical Cancer Screening in Belgium, Eur. J. Cancer;: 36:2191-2197.

Sulistiowati E. Sirait A.M. 2014. Pengetahuan Tentang Faktor Risiko, Perilaku dan Deteksi Dini Kanker Serviks dengan Inspeksi Visual Asam Asetat (IVA) pada Wanita di Kecamatan Bogor Tengah, Kota Bogor. Bulletin Penelitian Kesehatan:42(3);193-202.

Dethan C.M. \& Suariyani N.L.P. 2017. Pengetahuan dan Sikap tentang Perilaku Vaksinasi HPV pada Siswi SMA Swasta, Media Kesehatan Masyarakat Indonesia:13(2).

Rachmani B. Shaluhiyah Z. Cahyo K. 2012. Sikap Remaja Perempuan terhadap Pencegahan Kanker Serviks Melalui Vaksinasi HPV di Kota Semarang. Media Kesehatan Masyarakat Indonesia.

Safitry, R. 2016. Gambaran Pengetahuan Mahasiswi tentang Pemberian Vaksin HPV untuk Pencegahan Kanker Serviks di Prodi Kebidanan Fakultas Kedokteran dan Ilmu Kesehatan Universitas Islam Negeri Alauddin Makassar tahun 2016, Karya Tulis Ilmiah, Makasar: Universitas Islam Negeri Alauddin.

Joeharno. 2011. Analisis Faktor Risiko Kejadian Kanker Servik di Badan Layanan Umum Rumah Sakit dr. Wahidin Sudirohusodo Kota Makassar tahun 2001 2004.

Handayani D.T. Sudarso, Kusuma, A.M. 2013. Swamedikasi pada Mahasiswa Kesehatan dan Non Kesehatan, Jurnal Manajemen dan Pelayanan Farmasi; 3(3).

Rohmawati A. 2016. Swamedikasi di Kalangan Mahasiswa Kesehatan dan Non Kesehatan di Universitas Jember, Skripsi, Jawa Timur: Universitas Jember.

CDC. 2017. Genital HPV Infection - Fact Sheet. Diakses tanggal 5 Oktober 2017 melalui https://www.cdc.gov/std/hpv/stdfact-hpv.htm. 
Westra T.A. Rozenbaum M.H. Rogoza R.M. Nijman H.W. Daemen T. Postma M.J. Wilschut J.C. 2011. Until Which Age Should Women Be Vaccinated Against HPV Infection? Recommendation Based on Cost-effectiveness Analyses. The Journal of Infectious Diseases;204:377-84.

Sari A.P. Syahrul F. 2014. Faktor yang Berhubungan dengan Tindakan Vaksinasi HPV pada Wanita Usia Dewasa. Jurnal Berkala Epidemiologi; 2(3):321-330.

Shafei, M. N., Zainon, N., Zulkifli, N. F., \& Ibrahim, M. I. 2014. Knowledge and perception on human papilloma virus infection and vaccination among medical students of a university in Malaysia. Procedia - Social and Behavioral Sciences, $2707-2710$.

Yassine, Z., Samira, D., Salsabil, H., \& Abdelaaziz, A. 2016. Knowledge of Human Papillomavirus and Acceptability to Vaccinate in Adolescents and Young Adults of the Moroccan Population. J Pediatr Adolesc Gynecol, 292-298. 